\title{
Bisphosphonic Acid-Functionalized Cross-Linkers to Tailor Hydrogel Properties for Biomedical Applications
}

Melek N. Guven, ${ }^{\dagger, \perp}$ Merve S. Altuncu, ${ }^{\dagger, \perp}$ Tugba Bal, ${ }^{\ddagger}$ Dilem C. Oran, ${ }^{\ddagger}$ Umit Gulyuz, ${ }^{\|}$Seda Kizilel,,$\oplus$ Oguz Okay, ${ }^{\S}$ and Duygu Avci*, ${ }^{\circledR} \oplus$

${ }^{\dagger}$ Department of Chemistry, Bogazici University, Bebek, 34342 Istanbul, Turkey

${ }^{\ddagger}$ Department of Chemical and Biological Engineering, Koc University, Rumelifeneri Yolu, Sariyer, 34450 Istanbul, Turkey

${ }^{\S}$ Department of Chemistry, Istanbul Technical University, Maslak, 34469 Istanbul, Turkey

"Department of Chemistry and Chemical Processing Technologies, Kirklareli University, Luleburgaz, 39750 Kirklareli, Turkey

\author{
Supporting Information
}

ABSTRACT: Two bisphosphonic acid-functionalized crosslinkers (one novel) with different spacer chain characteristics were synthesized and incorporated into hydrogels by copolymerization with 2-hydroxyethyl methacrylate at different ratios to control the hydrogels' swelling, mechanical properties, and ability to support mineralization for biomedical applications. The cross-linkers were synthesized by reaction of 2-isocyanatoethyl methacrylate and bisphosphonated diamines followed by selective dealkylation of the bisphosphonate ester groups. The hydrogels provide in vitro growth of carbonated apatite, morphology affected by the cross-linker structure. The hydrogels exhibit a high Young's

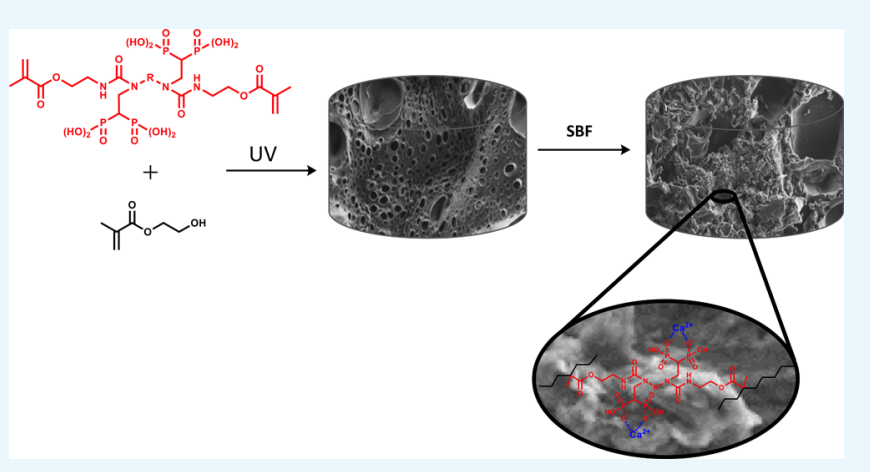
modulus $E$ (up to $400 \mathrm{kPa}$ ) and can sustain up to $10.2 \pm 0.1 \mathrm{MPa}$ compressive stresses. $E$ and hence the cross-link density significantly increases upon mineralization reflecting the formation of many bisphosphonate $\mathrm{BP}-\mathrm{Ca}^{2+}$ bonds acting as additional cross-links. Cyclic mechanical tests reveal self-recoverability of hydrogels because of reversible nature of $\mathrm{BP}-\mathrm{Ca}{ }^{2+}$ bonds. The results suggest that these cross-linkers can add calcium-binding abilities to hydrogels synthesized from any monomer and improve their mechanical, swelling, and mineralization properties and hence are potentially useful materials for biomedical applications.

\section{INTRODUCTION}

Hydrogels are three-dimensional hydrophilic polymeric networks, obtainable from a wide range of natural or synthetic hydrophilic polymers, which have various properties resembling living tissues; mostly because of their high water absorbing ability. ${ }^{1,2}$ This resemblance makes them attractive candidates for tissue engineering scaffolds. The properties of a hydrogel, such as swelling, porosity, elasticity, permeability to oxygen, various biological molecules, and nutrients, can in principle be tailored by the hydrogel's design aspects.

Tissue engineering, in the context of bones and bone-like tissues involves mineralization because these tissues are organic-inorganic hybrid composite matrices. For this purpose, it is appropriate to use hydrogels containing anionic groups, which are found to improve rates of biomineralization. The hydrogels can serve as organic templates within which hydroxyapatite ( $\left.\mathrm{HAP}, \mathrm{Ca}_{10}\left(\mathrm{PO}_{4}\right)_{6}(\mathrm{OH})_{2}\right)$ crystals can be synthesized; as in a way similar to natural bone. ${ }^{3-7}$ The hydrogel templates with designed chemical functionalities have the potential to control the type, shape, size, distribution, and organization of the inorganic crystals as well as specific cell binding during mineralization. The anionic functional groups such as phosphate, phosphonate, carboxylate, sulfonate, and hydroxyl can induce nucleation and growth of HAP under physiological conditions. ${ }^{4,8-13}$ The functional group also imparts properties such as hydrophilicity, bimolecular recognition, and enhanced cytocompatibility. ${ }^{4}$ The effect of chemical functionality as well as hydrophobicity of the templating matrix on mineralization has been well studied. ${ }^{14}$ The microstructure of the hydrogels coupled with the $\mathrm{pH}$ and gel strength also affects the formation of various nanocrystals such as brushite, octacalcium phosphate, monetite, and HAP in methacrylate-based hydrogels. ${ }^{15}$ The mineralization on anionic gelatin methacrylate hydrogels was found to be related to the changes in physicochemical properties of the hydrogel including its charge density and degree of swelling. ${ }^{10}$

Phosphorous-containing polymers have been implemented to improve and accelerate the formation of native tissue both by mimicking the native role of phosphorous groups in the body and by attachment of other bioactive molecules. ${ }^{16}$ The

Received: May 23, 2018

Accepted: July 23, 2018

Published: August 2, 2018 


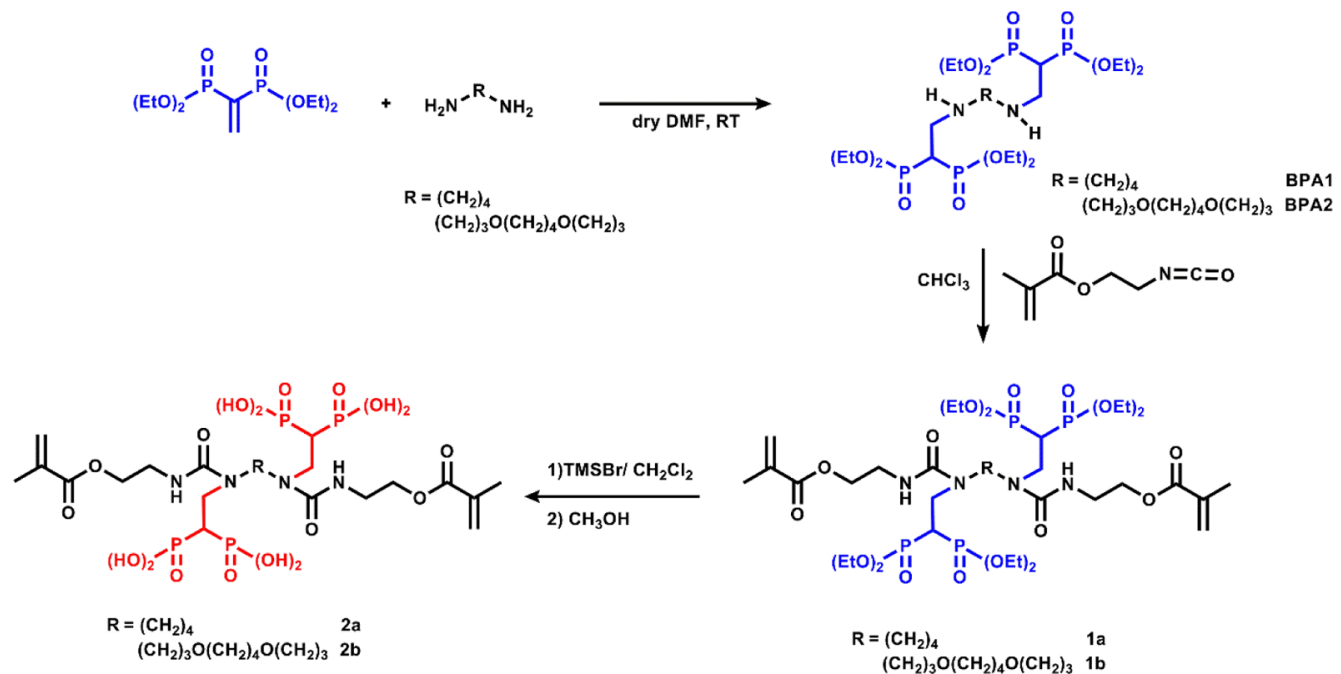

Figure 1. Synthesis of bisphosphonic acid-functionalized cross-linkers.

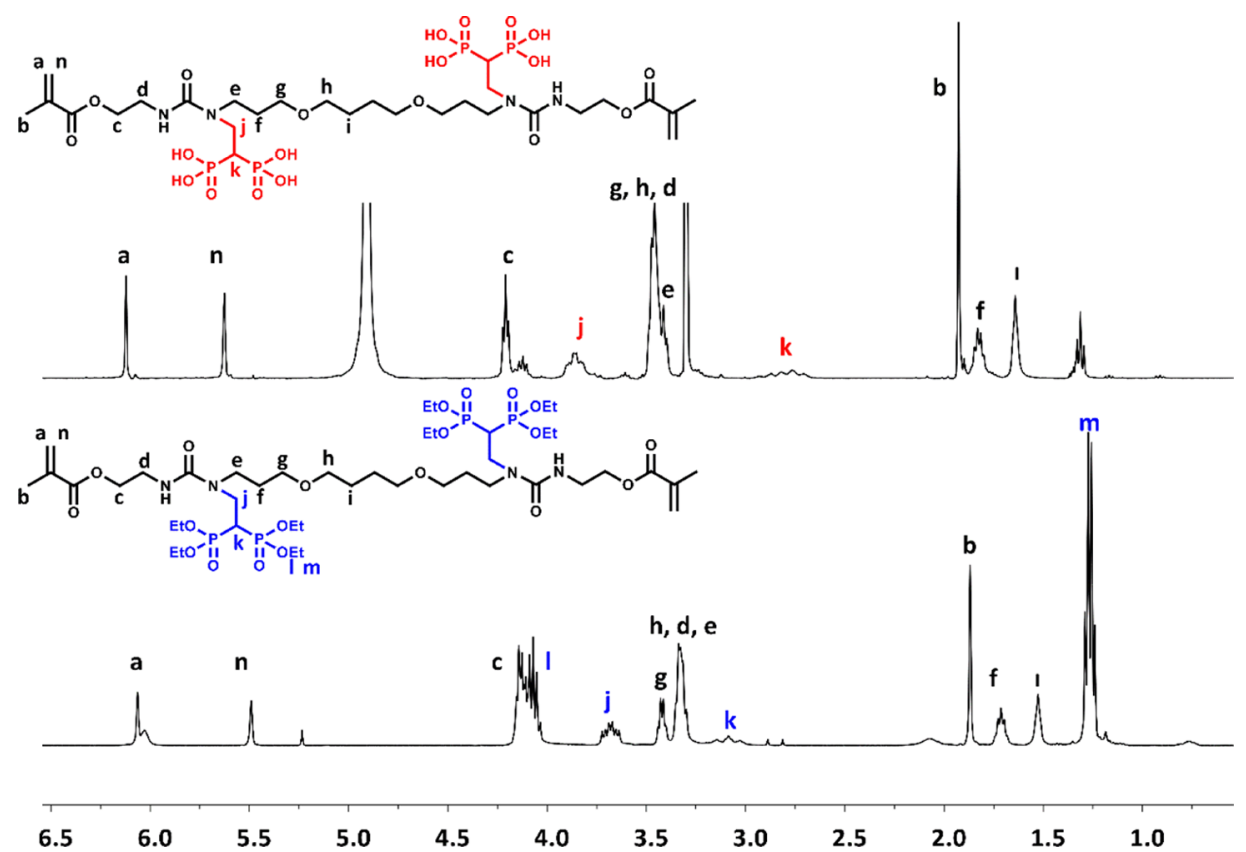

Figure 2. ${ }^{1} \mathrm{H}$ NMR spectra of $1 \mathrm{~b}$ and $2 \mathrm{~b}$.

hydrogels containing phosphate and phosphonate groups mineralize faster and more completely than analogues lacking the phosphorus-containing groups and also feature better cell adhesion and growth. ${ }^{17-27}$ In this context, Gemeinhart et al. developed a copolymer hydrogel of vinyl phosphonic acid (VPA) and acrylamide and found that at 30\% VPA concentration, osteoblast-like cells exhibit better proliferation, adhesion, differentiation, and ability to mineralize the polymer surface than at other concentrations of $\mathrm{VPA} ;{ }^{18}$ other work observed that ethylene glycol methacrylate phosphate-containing poly(ethylene glycol) (PEG) diacrylate hydrogels promote human mesenchymal stem cells adhesion and spreading; ${ }^{20}$ and hydrogels based on a phosphoester-PEG polymer promoted the gene expression of bone-specific markers including type I collagen and osteonectin without the addition of growth factors or other biological agents, compared with pure PEGbased gels. $^{24}$
Bisphosphonates (BPs) are structural analogues of naturally existing pyrophosphate with increased chemical and enzymatic stability. ${ }^{28}$ They have strong affinity for bone mineral, HAP, enabling them to chelate calcium ions and to prevent bone dissolution. $^{29}$ Therefore there is a growing interest in the use of BPs in combinations with scaffolds for bone tissue engineering. ${ }^{30}$ A hyaluronic acid (hyaluronan, HA) hydrogel functionalized with $\mathrm{BP}$ groups allows not only mineralization by the strong interaction between $\mathrm{BP}$ groups and $\mathrm{Ca}^{2+}$ ions but also release of bone morphogenic protein-2, necessary for bone formation, controlled by the amount of BP groups. ${ }^{31-33} \mathrm{HA}$ hydrogel with a chemical gradient of matrix-linked BP groups leads to graded biomineralization of the matrix. ${ }^{34}$ Nanocomposite hydrogels based on reversible bonds between calcium phosphate nanoparticles or bioactive glass and BPfunctionalized HA or gelatin display self-healing as well as adhesiveness to mineral surfaces such as HAP and show potential in bone-tissue engineering. ${ }^{35-37}$ Incorporation of 


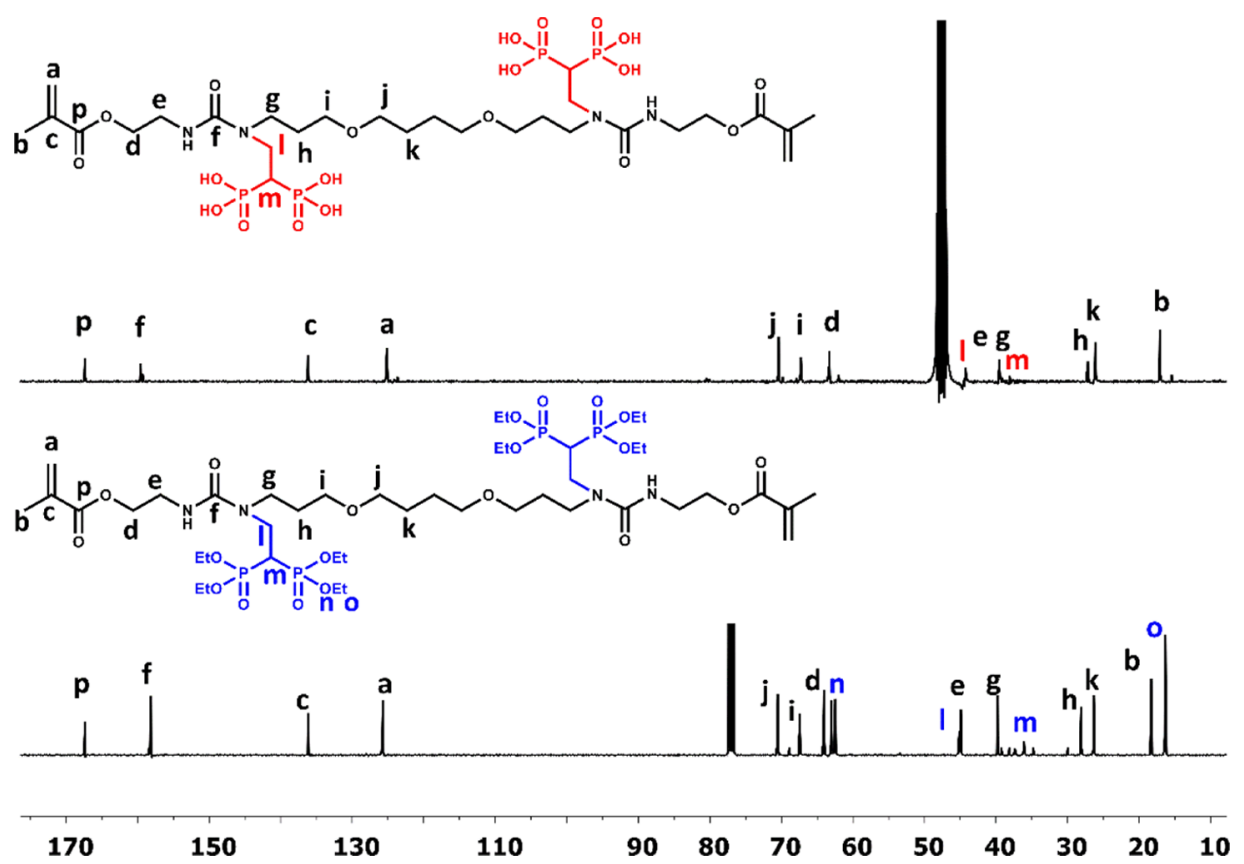

Figure $3 .{ }^{13} \mathrm{C}$ NMR spectra of $1 \mathrm{~b}$ and $2 \mathrm{~b}$.

bisphosphonic acid groups in dental monomer structures increases their interaction with dental tissues. In our previous work, urea dimethacrylates functionalized with BP and bisphosphonic acid groups were synthesized and evaluated for dental applications. ${ }^{38}$ The general structure of these monomers allows choice of different spacer chains between the double bonds, which will naturally modify their various properties.

The objective of this study was to synthesize bisphosphonic acid group containing cross-linkers, incorporate them in poly(2-hydroxyethyl methacrylate) hydrogels, and to investigate the effect of the bisphosphonic-acid functionalization on hydrogel properties. Because the bisphosphonic acid groups have strong affinity for bone, we also investigated the potential of these hydrogels as scaffolds for bone tissue engineering; so the hydrogels' mineralization, mechanical properties, and change of mechanical properties with mineralization was studied, especially with this application in mind.

\section{RESULTS AND DISCUSSION}

Synthesis of Cross-linkers. Two bisphosphonic acidfunctionalized urea dimethacrylates $(2 \mathrm{a}, 2 \mathrm{~b})$ with different spacer chain characteristics between double bonds were synthesized and used as cross-linkers for fabrication of 2hydroxyethyl methacrylate (HEMA)-based hydrogels. Monomers $(2 a, 2 b)$ were synthesized by the reaction of two bisphosphonated amines (BPA1 and BPA2) with 2-isocyanatoethyl methacrylate (IEM) to form BP-containing monomers (1a, 1b), followed by the dealkylation of the BP groups by trimethylsilyl bromide (TMSBr) (Figure 1). Synthesis of 1a and $2 \mathrm{a}$ as well as their starting amine BPA1 was reported earlier by $u ;^{38,39}$ however, $1 \mathrm{~b}$ and $2 \mathrm{~b}$ are novel. The acidic monomers $(2 \mathrm{a}, 2 \mathrm{~b})$ were obtained as white colored waxy solids in $52-75 \%$ yields. All of the monomers ( $1 \mathrm{a}, 1 \mathrm{~b}, 2 \mathrm{a}$, and $2 \mathrm{~b}$ ) are well soluble in water (Table S1). The acid monomers $2 \mathrm{a}$ and $2 \mathrm{~b}$ are insoluble in weakly polar compounds such as ether as opposed to $1 \mathrm{a}$ and $1 \mathrm{~b}$.
The structures of the monomers were confirmed by Fourier transform infrared (FTIR), ${ }^{1} \mathrm{H}$ NMR, and ${ }^{13} \mathrm{C} \quad \mathrm{NMR}$ spectroscopy. ${ }^{1} \mathrm{H}$ NMR spectrum of $1 \mathrm{~b}$ shows characteristic peaks of methine protons as a triplets of triplet at $3.09 \mathrm{ppm}$, methylene protons attached to methine as triplet of doublets at $3.68 \mathrm{ppm}$, and double-bond protons at 5.49 and $6.06 \mathrm{ppm}$. The broad peak next to one of the double bonds $(6 \mathrm{ppm})$ indicates $\mathrm{NH}$ protons (Figure 2). In the ${ }^{13} \mathrm{C}$ NMR spectrum of $1 \mathrm{~b}$, the triplet seen at $36.18 \mathrm{ppm}$ is due to the methine carbon attached to phosphorus (Figure 3 ). The NMR spectra of $2 \mathrm{~b}$ support the dealkylation process with the almost complete disappearance of ethyl peaks of the phosphonate groups (1.27, $4.07 \mathrm{ppm}$ in ${ }^{1} \mathrm{H}$ NMR and 16.42, 63.01-62.48 $\mathrm{ppm}$ in ${ }^{13} \mathrm{C}$ NMR) (Figures 2 and 3). The FTIR spectra of the acid monomers show broad peaks in the region of 3200-2600 and $2300-2100 \mathrm{~cm}^{-1}$ due to $\mathrm{OH}$ stretching and strong peaks at 1712 , and $1699 \mathrm{~cm}^{-1}$ because of two different $\mathrm{C}=\mathrm{O}$ stretchings (Figure 4). Also, the strong bands at 996 and $912 \mathrm{~cm}^{-1}$ correspond to the symmetric and asymmetric vibration of $\mathrm{P}-\mathrm{O}$.

Synthesis of Hydrogels. Bisphosphonic acid-functionalized cross-linkers $2 \mathrm{a}$ and $2 \mathrm{~b}$ were copolymerized with HEMA via photoinitiated polymerization to obtain hydrogels containing pendant bisphosphonic acid groups. The hydrogel compositions are shown in Table 1, where the designation of each composition shows after the letter $\mathrm{H}$ for hydrogel, the cross-linker used, the cross-linker's weight percentage in the monomer mixture, and the weight percentage of the monomer mixture in the solution. For instance $\mathrm{H} 2 \mathrm{a}: 10: 25$ denotes the hydrogel prepared using $10 \mathrm{wt} \% 2 \mathrm{a}$ cross-linker at a total monomer (2a + HEMA) concentration of 25 wt \%. The hydrogels were obtained with a gel fraction $W_{\mathrm{g}}$ between 73 and 92\% (Table 1). The scanning electron microscopy (SEM) images of these hydrogels showed porous structures because of the lyophilization process (Figure 5), but different morphologies indicate that the cross-linker structure affects the hydrogels' microstructure. 


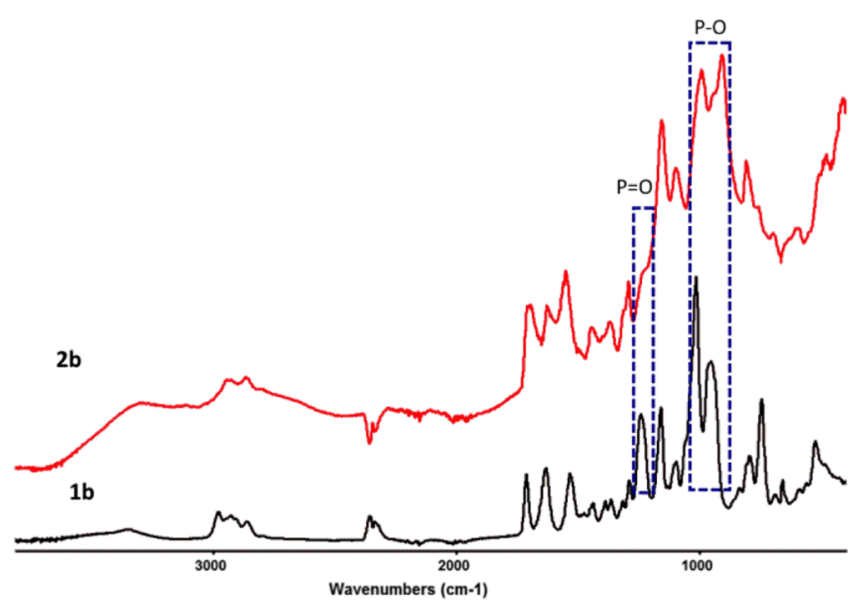

Figure 4. IR spectra of $1 b$ and $2 b$.

Table 1. Feed Compositions of Hydrogels and Gel Fractions

\begin{tabular}{lcccc} 
hydrogels & cross-linker & $\begin{array}{c}\text { monomer } \\
\text { composition } \\
\text { HEMA/2a or } 2 \mathrm{~b} \\
\text { (wt/wt) }\end{array}$ & $\begin{array}{c}\text { total monomer } \\
\text { concentration } \\
\text { (wt \%) }\end{array}$ & $W_{\mathrm{g}}(\%)$ \\
H0:0:25 & & $100 / 0$ & 25 & 91 \\
H0:0:20 & & $100 / 0$ & 20 & 90 \\
H2a:5:25 & $2 \mathrm{a}$ & $95 / 5$ & 25 & 83 \\
H2a:10:25 & $2 \mathrm{a}$ & $90 / 10$ & 25 & 80 \\
H2a:10:20 & $2 \mathrm{a}$ & $90 / 10$ & 20 & 87 \\
H2a:20:25 & $2 \mathrm{a}$ & $80 / 20$ & 25 & 75 \\
H2a:20:20 & $2 \mathrm{a}$ & $80 / 20$ & 20 & 78 \\
H2b:5:25 & $2 \mathrm{~b}$ & $95 / 5$ & 25 & 73 \\
H2b:5:20 & $2 \mathrm{~b}$ & $95 / 5$ & 20 & \\
H2b:10:25 & $2 \mathrm{~b}$ & $90 / 10$ & 25 & 83 \\
H2b:10:20 & $2 \mathrm{~b}$ & $90 / 10$ & 20 & 80 \\
H2b:20:25 & $2 \mathrm{~b}$ & $80 / 20$ & 25 & 92 \\
\hline
\end{tabular}

Swelling Studies. The swelling behavior of the hydrogels prepared using $2 \mathrm{a}$ and $2 \mathrm{~b}$ cross-linkers was studied in water and in $1 \mathrm{M} \mathrm{CaCl}_{2}$ solution (Figure 6). Because $2 \mathrm{a}$ and $2 \mathrm{~b}$ cross-linkers are strong electrolytes, bisphosphonic acid groups are expected to be fully ionized even in water for both of the hydrogels. $2 \mathrm{~b}$ has longer and more hydrophilic chain segments between cross-link junctions. In addition, hydrogels prepared from $2 \mathrm{~b}$ will have less cross-linking density at the same composition (wt \%) because of its slightly higher molecular weight $(890 \mathrm{~g} / \mathrm{mol})$ compared with $2 \mathrm{a}(774 \mathrm{~g} / \mathrm{mol})$. Therefore, the hydrogels prepared from $2 \mathrm{~b}$ might be expected to have higher swelling extent than those prepared from 2a. However, the swelling behavior of the hydrogels does not agree with this expectation. The hydrogels based on $2 \mathrm{a}$ showed higher percentage of swelling (SP) than those of $2 \mathrm{~b}$-based ones, which may be explained by the higher concentration of hydrophilic bisphosphonic acid groups in the first one. This means that the hydrophilic effect of the bisphosphonic acid groups overcomes the expected tendency of shorter crosslinkers to produce denser networks; moreover, it also dominates over the hydrophilic effect of the linkage. Furthermore, increasing the amount of cross-linker from 5 (H2a:5:20 and H2b:5:20) to 10 wt \% (H2a:10:20 and $\mathrm{H} 2 \mathrm{~b}: 10: 20)$ leads to an increase in the degree of swelling. This is expected because of the simultaneous increase of the hydrophilicity of the polymer network. Increasing the total monomer concentration from 20 to $25 \mathrm{wt} \%$ at a fixed cross-
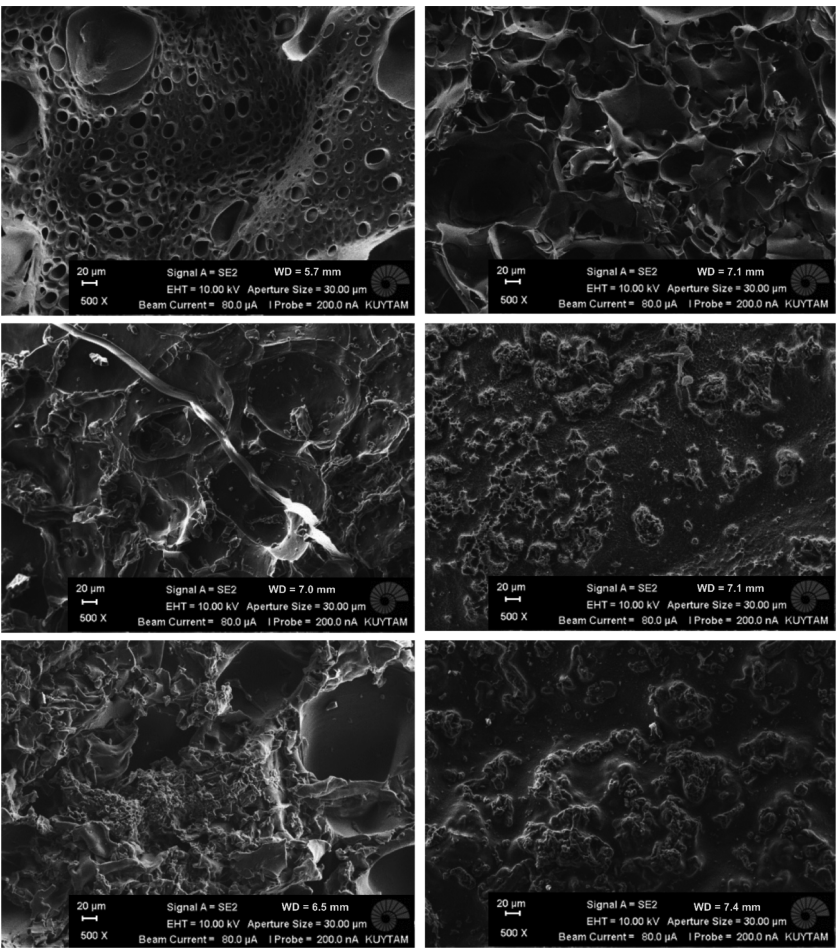

Figure 5. SEM images of (top) hydrogels before mineralization, (middle) after 2 weeks of mineralization, and (bottom) after 4 weeks of mineralization. Left column shows the H2a:10:20 hydrogel, right column, H2b:10:20 hydrogel.

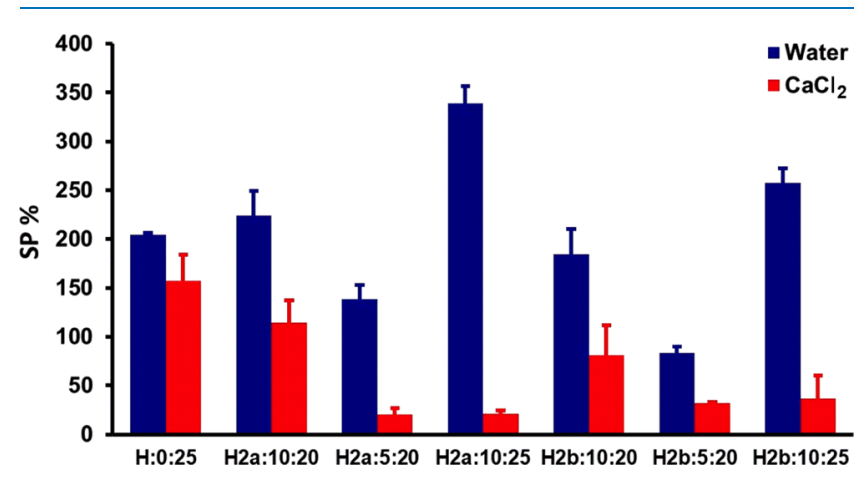

Figure 6. SP of the hydrogels.

linker content also increases the degree of swelling, and the maximum swelling percentages of 350 and 275 were recorded for H2a:10:25 and H2b:10:25 hydrogels, respectively. The hydrogels immersed in $1 \mathrm{M} \mathrm{CaCl}_{2}$ solution showed lower swelling because of the formation of physical cross-linking through BP groups.

Mineralization of Hydrogels. It is known that the interaction of acid functional monomers with calcium or HAP can be influenced by the alkyl chain length or chains with different hydrophilicities in their structures. ${ }^{40}$ It was also shown that small changes in matrix hydrophobicity can influence the $\mathrm{Ca}^{2+}$ binding and formation of HAP-like mineral phases on hydrogel matrices. For example, PEG hydrogels modified with varying lengths of anionic pendant side chains promotes mineralization for chains containing up to five methylene groups, a further increase in side-chain length causes a reduction of apatite nucleation. ${ }^{14}$ Therefore, it is natural to expect that mineralization of calcium phosphates on 
HEMA hydrogels synthesized with $2 \mathrm{a}$ or $2 \mathrm{~b}$ will be significantly different.

Mineralization experiments of the synthesized hydrogels were performed in simulated body fluid (SBF), which closely mimics the ionic concentrations and $\mathrm{pH}$ typically observed in plasma. After soaking in SBF for 2 and 4 weeks, their mineralization was studied using FTIR, SEM, X-ray diffractometer (XRD), energy-dispersive X-ray (EDX), and calcium assay. The $\mathrm{Ca}^{2+}$ content of the hydrogels was determined using the calcium assay (Figure 7). The amount of calcium reached

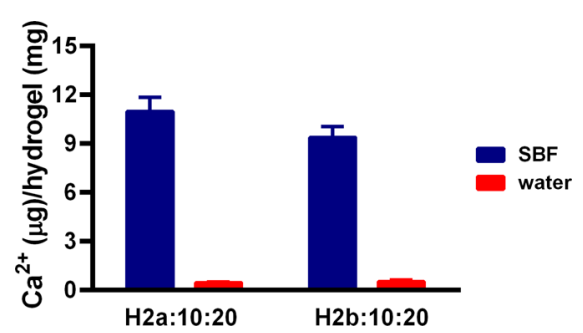

Figure 7. $\mathrm{Ca}^{2+}$ content of the hydrogels (H2a:10:20 and H2b:10:20) after 4 weeks of mineralization in water (control) and SBF.

after 4 weeks of incubation was $11 \pm 1$ and $9.4 \pm 0.7 \mu \mathrm{g} / \mathrm{mg}$ of dry $\mathrm{H} 2 \mathrm{a}: 10: 20$ and $\mathrm{H} 2 \mathrm{~b}: 10: 20$ hydrogels. Both types of hydrogels exhibited similar and high calcium content, indicating the role of bisphosphonic acid functional group in the nucleation of minerals. The small difference in the extent of mineralization can be explained by the higher concentration of bisphosphonic acid functionality in 2a-based hydrogels compared with that of $2 b$-based ones, as well as structural differences between cross-linkers.

SEM images indicated that the hydrogels were covered with a mineral layer with spherical mineral clusters (Figure 5). EDX was used to determine the elemental content of the mineralized hydrogels and showed the presence of $\mathrm{C}, \mathrm{O}, \mathrm{P}$, $\mathrm{Ca}$, and $\mathrm{Mg}$ in all mineralized samples. The presence of $\mathrm{Mg}^{2+}$ is probably due to substitution of $\mathrm{Ca}^{2+}$ within the $\mathrm{CaP}$ lattice. ${ }^{41}$ Therefore, Suzuki et al. evaluated both $\mathrm{Ca} / \mathrm{P}$ and $(\mathrm{Ca}+\mathrm{Mg}) / \mathrm{P}$ ratios in their mineralization experiments. ${ }^{42}$ The hydrogels before mineralization did not show $\mathrm{Ca}$ and $\mathrm{Mg}$ ions, the intensity of the $\mathrm{P}$ peak was much lower than that of the mineralized hydrogels (Figure 8). The $\mathrm{Ca} / \mathrm{P}$ and $(\mathrm{Ca}+\mathrm{Mg}) / \mathrm{P}$ ratios of the mineral layers were found to be $0.8-1.08$ and 1.21 and 1.40 for $\mathrm{H} 2 \mathrm{a}: 10: 20$ and $\mathrm{H} 2 \mathrm{~b}: 10: 20$ hydrogels, respectively. HAP is the major component of bone and other biological apatites; therefore, the theoretical stoichiometric ratio of calcium to phosphate $(\mathrm{Ca} / \mathrm{P})$ is $1.67 .^{42} \mathrm{The} \mathrm{Ca} / \mathrm{P}$ ratios in amorphous calcium phosphate $\left[\mathrm{Ca}_{3}\left(\mathrm{PO}_{4}\right)_{2}\right]$, brushite $\left[\left(\mathrm{CaHPO}_{4}\right)_{3}-\mathrm{H}_{2} \mathrm{O}\right]$, and octacalcium phosphate $\left[\mathrm{Ca}_{8}\left(\mathrm{PO}_{4}\right)_{6} \mathrm{H}_{2}\right]$ are $1.5,1.0$, and 1.33 , respectively. ${ }^{43}$ These results indicate that the mineral regions of the mineralized hydrogels have composition similar to biological apatite. The XRD spectra of mineralized hydrogels were similar to those of biological apatites, especially with respect to the peak at $32^{\circ}$ (Figure 9). ${ }^{44}$ It was also observed that mineralization was

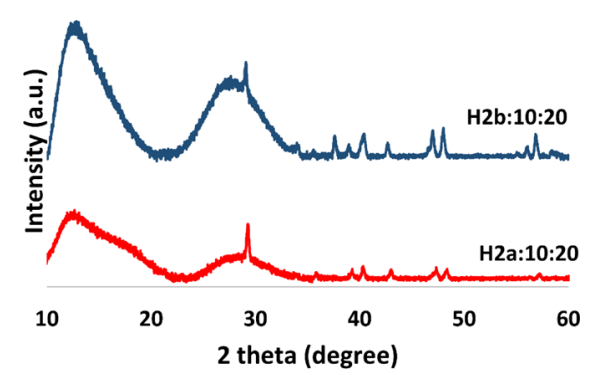

Figure 9. X-ray diffraction spectra for hydrogels after 2 weeks of mineralization in SBF.

favored by hydrogels containing $2 \mathrm{~b}$ compared with that of $2 \mathrm{a}$. The longer chain of $2 \mathrm{~b}$ increases flexibility and may allow the $\mathrm{Ca}^{2+}$ bound chains to attain conformations favoring the formation of apatite crystals.

Mechanical Properties. Mechanical properties of the synthesized hydrogels were determined by uniaxial compression tests. Figures 10a,b presents typical stress-strain curves of $\mathrm{H} 2 \mathrm{a}: \mathrm{X}: 25$ and $\mathrm{H} 2 \mathrm{~b}: \mathrm{X}: 25$ hydrogels equilibrium swollen in
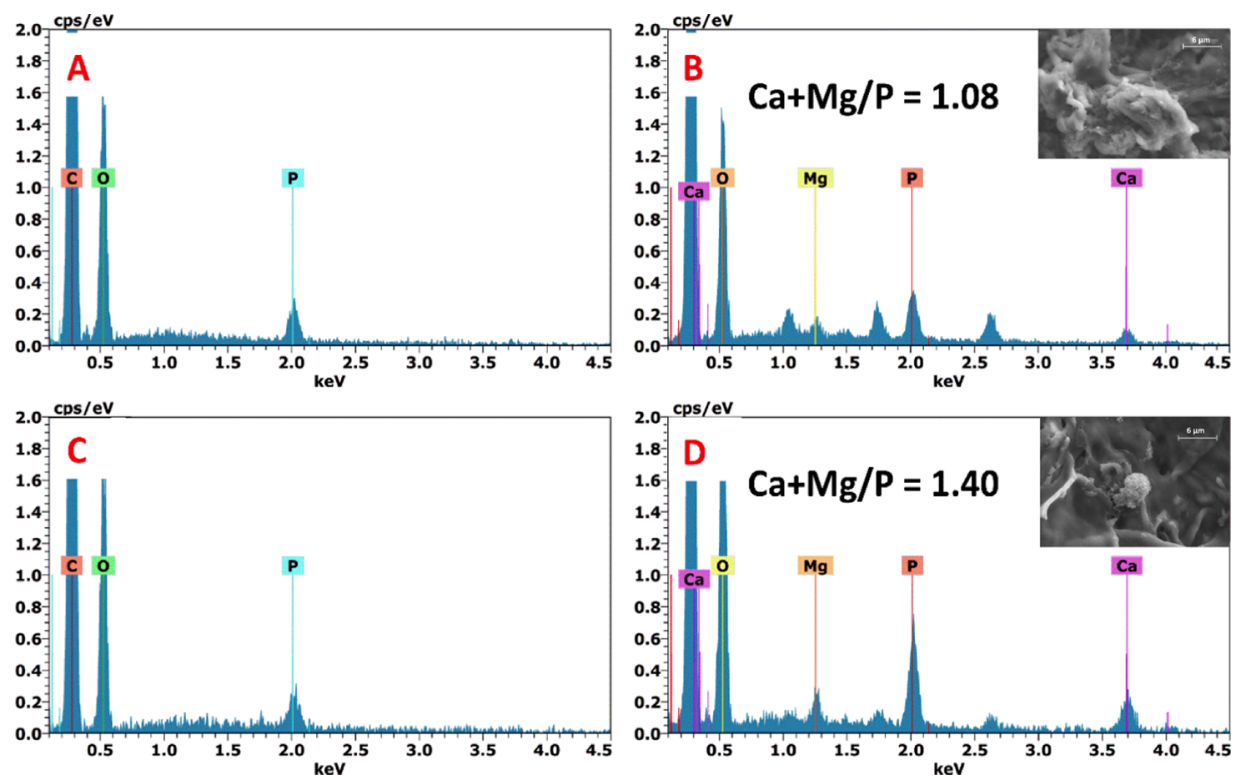

Figure 8. EDX analysis of hydrogels after 4 weeks of mineralization in water (control) and SBF: (A,B) show H2a:10:20 hydrogel, (C,D) $\mathrm{H} 2 \mathrm{~b}: 10: 20$ hydrogel. 


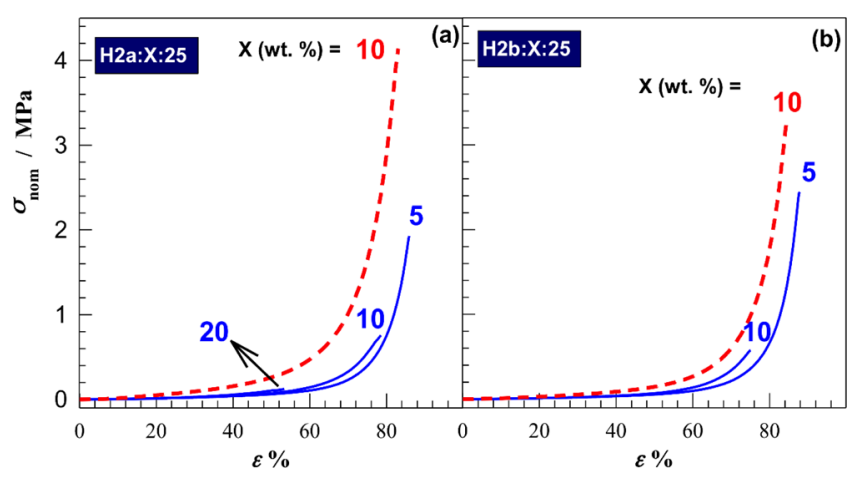

Figure 10. Stress-strain curves of H2a:X:25 (a) and H2b:X:25 hydrogels (b) at various cross-linker contents in water (solid curves) and in aqueous $1 \mathrm{M} \mathrm{CaCl}_{2}$ solution (dashed curves). Nominal stress $\sigma_{\text {nom }}$ is plotted against strain $\varepsilon$ at a strain rate of $1.8 \times 10^{-2} \mathrm{~s}^{-1}$.

water (solid blue curves) and in aqueous $1 \mathrm{M} \mathrm{CaCl}_{2}$ solution (dashed red curves). The content of the cross-linker X ( $2 \mathrm{a}$ or $2 \mathrm{~b})$ is indicated. For both cross-linkers, increasing the crosslinker content decreases the fracture stress and strain of the hydrogels in water. However, when measured in $\mathrm{CaCl}_{2}$ solution instead of water (dashed vs solid curves), the fracture stress and hence the energy to break (toughness) significantly increases. For instance, the toughness of H2a:10:25 hydrogel calculated from the area under the stress-strain curve up to the fracture point increases fivefold upon immersion in $1 \mathrm{M}$ $\mathrm{CaCl}_{2}$ solution (from $88 \pm 10$ to $430 \pm 30 \mathrm{~kJ} \cdot \mathrm{m}^{-3}$ ). A similar increase in toughness is also observable for H2b:10:25 hydrogel (from $66 \pm 8$ to $312 \pm 25 \mathrm{~kJ} \cdot \mathrm{m}^{-3}$ ). The toughness improvement in the hydrogel can be explained with the formation of noncovalent bonds between bisphosphonic acid groups and $\mathrm{Ca}^{2+}$ ions in the salt solution. These physical crosslinks acting as reversible sacrificial bonds that easily break under stress, dissipate energy and hence prevent crack propagation and macroscopic fracture at low stresses. ${ }^{45,46}$

In Figure 11, Young's modulus $E$ and fracture stress $\sigma_{\mathrm{f}}$ of $\mathrm{H} 2 \mathrm{a}: \mathrm{X}: 25$ hydrogels in water (circles) and in $1 \mathrm{M} \mathrm{CaCl}_{2}$
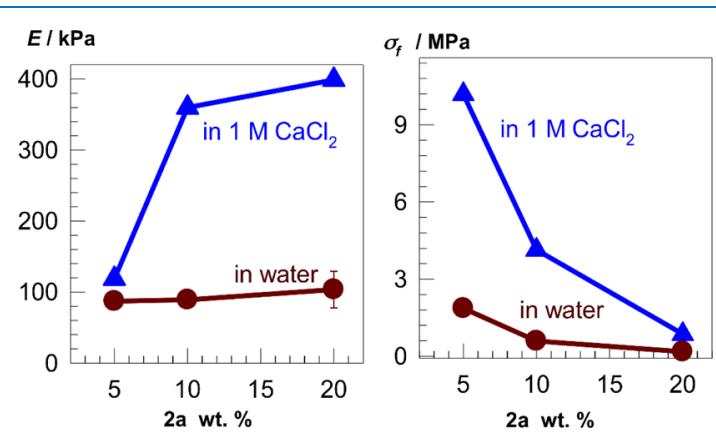

Figure 11. Young's modulus $E$ and fracture stress $\sigma_{\mathrm{f}}$ of the hydrogels in water (circles) and in aqueous $1 \mathrm{M} \mathrm{CaCl}_{2}$ solution (triangles) plotted against the cross-linker (2a) content. Total monomer concentration $=25$ wt $\%$.

solution (triangles) are plotted against the cross-linker (2a) content. It is seen that the modulus $E$ of the hydrogel measured in water does not change with the increasing crosslinker (2a) content, whereas it rapidly increases when measured in $1 \mathrm{M} \mathrm{CaCl}$ solution. For instance, $E$ of $\mathrm{H} 2 \mathrm{a}: 20: 25$ hydrogel is $104 \pm 25$ and $400 \pm 30 \mathrm{kPa}$ in water and in $\mathrm{CaCl}_{2}$ solution, respectively. This finding also reflects the formation of noncovalent cross-links due to the $\mathrm{Ca}^{2+}$ ions contributing significantly to the cross-link density and hence to the modulus of the hydrogels. Because these additional cross-links are reversible in nature, they lead to about 10 -fold increase in the fracture stress of the hydrogels. The results also show that when immersed in $\mathrm{CaCl}_{2}$ solution, 2a-based hydrogels are mechanically stronger than $2 \mathrm{~b}$-based ones indicating stronger bisphosphate- $\mathrm{Ca}^{2+}$ interactions in the former hydrogels (Figure S1). This can be explained by the lower molecular weight of $2 \mathrm{a}$ as compared to $2 \mathrm{~b}$, leading to higher concentration of bisphosphonic acid groups in 2a-based hydrogels. The results also reveal that incubation of hydrogel samples in the $\mathrm{Ca}^{2+} / \mathrm{Mg}^{2+}$ containing SBF during mineralization would also lead to their strengthening.

We also observed that reducing the monomer concentration at the gel preparation significantly improves the mechanical properties. For instance, the solid and dashed curves in Figure $12 \mathrm{a}$ are stress-strain curves of the hydrogels prepared at a monomer concentration of 20 and 25 wt \%, respectively. The cross-linker $(2 \mathrm{~b})$ concentration was fixed at $10 \mathrm{wt} \%$. Although the modulus $E$ decreases from $78 \pm 2$ to $32 \pm 1 \mathrm{kPa}$ with decreasing monomer concentration because of the dilution of the network chains, the fracture stress $\sigma_{\mathrm{f}}$ significantly increases from 0.5 to $9.4 \pm 1.1 \mathrm{MPa}$. The hydrogel formed at $20 \mathrm{wt} \%$ concentration sustains up to about $96 \%$ compression ratios. Because the chemically cross-linked hydrogels are generally brittle in nature, the results suggest existence of the reversible intermolecular bisphosphonic acid bonds in the hydrogels contributing to their mechanical properties.

Cyclic mechanical tests could provide a mean to detect the existence of reversible cross-links in hydrogels. ${ }^{45,46}$ Such tests were conducted by compressing hydrogel samples up to a maximum strain $\varepsilon_{\max }$ (loading step), followed by retraction to zero force (unloading step) and a waiting time of $5 \mathrm{~min}$ before the next cycle of compression. Figure $12 b, c$ shows typical results of three successive loading/unloading experiments conducted on $\mathrm{H} 2 \mathrm{~b}: 10: 20$ hydrogel specimens. The tests were conducted by increasing $\varepsilon_{\max }$ from 50 to $90 \%$ (b) and for three successive cycles up to $\varepsilon_{\max }=90 \%$ (b). The loading and unloading curves are shown by the solid and dashed curves, respectively. The loading curve is always different from the unloading curve ("hysteresis behavior") indicating damage in the gel sample and dissipation of energy. However, each loading curve follows the path of the previous loading indicating that the damage in the gel is repaired during 5 min of waiting time between the cycles. The hysteresis energies $U_{\text {hys }}$ were calculated from the area between loading and unloading curves. The inset in Figure $12 \mathrm{c}$ shows $U_{\text {hys }}$ plotted against the maximum strain $\varepsilon_{\max }$ (circles) and the number of cycles for $\varepsilon_{\max }=90 \%$ (triangles). $U_{\text {hys }}$ increases with $\varepsilon_{\max }$ revealing that increasing number of bonds are reversibly broken as the strain is increased. For $\varepsilon_{\max }=90 \%, U_{\text {hys }}$ is almost constant $\left(78 \pm 14 \mathrm{~kJ} \cdot \mathrm{m}^{-3}\right)$ in three successive cycles indicating self-recoverability of the present hydrogels.

To highlight the effect of $\mathrm{Ca}^{2+}$ ions on the number of noncovalent bonds reversibly broken under strain, cyclic mechanical tests were conducted on $\mathrm{H} 2 \mathrm{a}: 10: 20$ hydrogel specimens immersed in water and in $1 \mathrm{M} \mathrm{CaCl}_{2}$ solution. The results are shown in Figure 13a,b for four successive cycles with increasing $\varepsilon_{\max }$ from 50 to $80 \%$ compression. The inset showing the $\varepsilon_{\max }$-dependence of $U_{\text {hys }}$ reveals that $U_{\text {hys }}$ is much larger in $\mathrm{CaCl}_{2}$ solution than in water. Moreover, the larger the $\varepsilon_{\max }$ the larger the difference is between the $U_{\text {hys }}$ 's measured in 

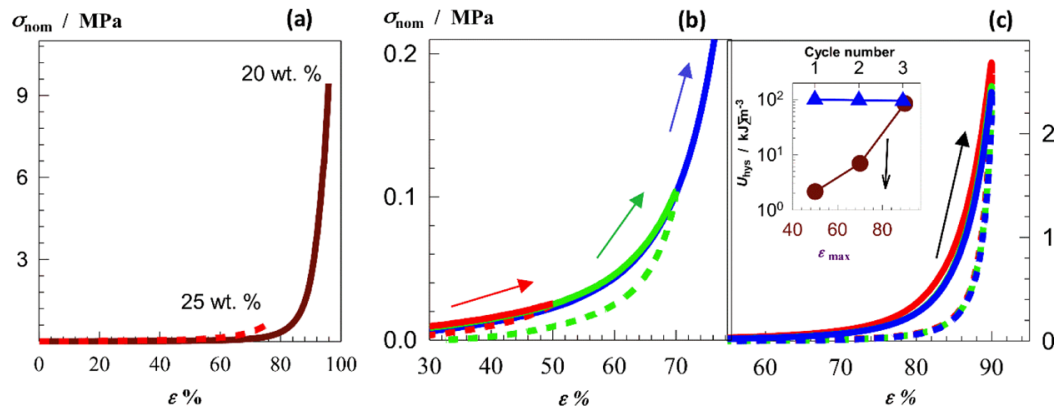

Figure 12. (a) Stress-strain curves of H2b:10:20 (solid curve) and H2b:10:25 hydrogels (dashed curve) formed at monomer concentrations of 20 and $25 \mathrm{wt} \%$, respectively. (b,c) Cyclic compressive test results with increasing maximum strain $\varepsilon_{\max }$ from 50 to $90 \%$ (b) and for 3 successive cycles up to $\varepsilon_{\max }=90 \%$ (c) for $\mathrm{H} 2 \mathrm{~b}: 10: 20$ hydrogel equilibrium swollen in water. The inset to (c) shows the hysteresis energy $U_{\text {hys }}$ plotted against $\varepsilon_{\max }$ (circles) and the number of cycles up to $\varepsilon_{\max }=90 \%$ (triangles).

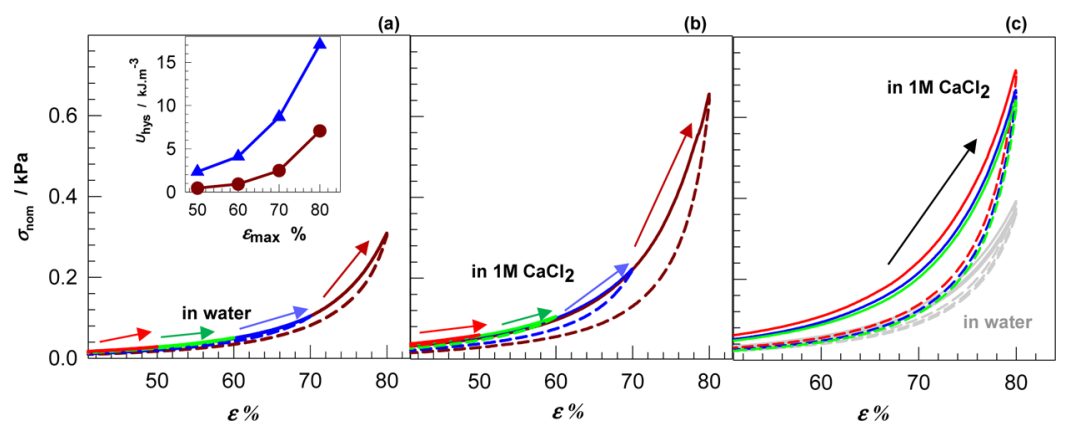

Figure 13. (a,b) Cyclic compressive test results of $\mathrm{H} 2 \mathrm{a}: 10: 20$ hydrogels immersed in water (a) and in $1 \mathrm{M} \mathrm{CaCl}_{2}$ solution (b) with increasing maximum strain $\varepsilon_{\max }$ from 50 to $80 \%$. The inset to (a) shows the hysteresis energy $U_{\text {hys }}$ plotted against $\varepsilon_{\max }$ for the hydrogels in water (circles) and in $1 \mathrm{M} \mathrm{CaCl}_{2}$ solution (triangles). (c) Three successive compressive cycles up to $\varepsilon_{\max }=80 \%$ for $\mathrm{H} 2 \mathrm{a}: 10: 20$ hydrogels immersed in water and in 1 $\mathrm{M} \mathrm{CaCl}_{2}$ solution.

water and in $\mathrm{CaCl}_{2}$ solution indicating stronger bisphosphonate $\mathrm{BP}-\mathrm{Ca}^{2+}$ bonds as compared to hydrogen bonds between BPs. Figure $13 \mathrm{c}$ presents three successive cycles up to $\varepsilon_{\max }=$ $80 \%$ conducted on $\mathrm{H} 2 \mathrm{a}: 10: 20$ hydrogels in water and in $\mathrm{CaCl}_{2}$ solution. The reversibility of the cycles is obvious with hysteresis energies $U_{\text {hys }}=7.7 \pm 0.4$ and $27 \pm 3 \mathrm{~kJ} \cdot \mathrm{m}^{-3}$ in water and in $\mathrm{CaCl}_{2}$ solution, respectively. $U_{\text {hys }}$ that is 3.5 -fold larger in the presence of $\mathrm{Ca}^{2+}$ ions indicates the reversible nature of additional $\mathrm{BP}-\mathrm{Ca}^{2+}$ bonds. The results thus reveal that the hydrogels presented here have the ability to selfrecover without any external stimulus.

\section{CONCLUSIONS}

The use of bisphosphonic acid-functionalized dimethacrylates as cross-linkers in the synthesis of biomaterials for mineralization was shown in HEMA-based hydrogels. The presence of bisphosphonic acid groups regulates calcium binding to the hydrogels and results in mineral growth in SBF. The composition of the mineral was a carbonate apatite similar to bone mineral. It was observed that the cross-linker structure could strongly influence the extent of mineralization, $2 b$ higher than $2 \mathrm{a}$. The swelling degree increases with an increase of the cross-linker concentration because of an increase in anionic charges and overcomes the competition between the crosslinking density and the anionic charges brought by the crosslinkers. The hydrogels obtained using bisphosphonic acidfunctionalized containing cross-linkers exhibit a high Young's modulus (up to $400 \mathrm{kPa}$ ) and can sustain up to $10.2 \pm 0.1$ $\mathrm{MPa}$ compressive stresses. The modulus and hence the crosslink density of the hydrogels significantly increased upon mineralization because of the additional $\mathrm{BP}-\mathrm{Ca}^{2+}$ cross-links.
For instance, Young's modulus E of the hydrogels prepared at 20 wt \% cross-linker content increases from $104 \pm 25$ to $400 \pm$ $30 \mathrm{kPa}$ upon replacing water with $1 \mathrm{M} \mathrm{CaCl}_{2}$ solution, reflecting the formation of a large number $\mathrm{BP}-\mathrm{Ca}^{2+}$ bonds acting as cross-linkers. Cyclic mechanical tests reveal selfrecoverability of the hydrogels at room temperature because of the reversible nature of $\mathrm{BP}-\mathrm{Ca}^{2+}$ bonds. These results imply that the bisphosphonic acid functionalized cross-linkers are good candidates for use in tissue engineering applications.

\section{EXPERIMENTAL SECTION}

Materials. 1,4-Butanediamine, 4,9-dioxa-1,12-dodecanediamine, tetraethyl methylenebisphosphonate, IEM, HEMA, 2hydroxy-1-[4-(2-hydroxyethoxy)phenyl]-2-methyl-1-propanone) (Irgacure 2959), TMSBr, and all other reagents and solvents were purchased from Sigma-Aldrich Chemical Co. (Taufkirchen, Germany) and used as received without any further purification. Tetraethyl ethenylidene bisphoshonate was synthesized from tetraethyl methylenebisphosphonate as described by Degenhardt and Burdsall. ${ }^{47}$ Two BP-functionalized amines (BPA1 and BPA2) were synthesized as reported by our group. ${ }^{39}$ Dichloromethane (DCM) (Merck) was dried over activated molecular sieves.

Characterization. The chemical structures of BP-functionalized diamines and cross-linkers were proved by ${ }^{1} \mathrm{H} \mathrm{NMR},{ }^{13} \mathrm{C}$ NMR, and FTIR spectroscopies. NMR spectra were recorded on a Varian Gemini $400 \mathrm{MHz}$ spectrometer using deuterated chloroform $\left(\mathrm{CDCl}_{3}\right)$ or methanol $(\mathrm{MeOD})$ as solvent and tetramethylsilane as an internal standard. FTIR spectra were recorded on Thermo Scientific Nicolet 6700 spectrometer. Combi Flash Companion Teledyne ISCO Flash Chromatog- 
raphy with $\mathrm{C} 18$ reverse-phase silica gel as a stationary phase was used for purification of cross-linkers.

General Procedure for the Synthesis of Monomers 1a and $1 \mathrm{~b}$. IEM ( $3.54 \mathrm{mmol}, 0.5 \mathrm{~mL}$ ) was added dropwise to an ice-cold solution of the synthesized diamine BPA1 or BPA2 $(1.73 \mathrm{mmol})$ in $12 \mathrm{~mL}$ of dry chloroform under a stream of nitrogen. The solution was stirred at room temperature overnight under nitrogen and then extracted with 1 wt \% $\mathrm{HCl}(2 \times 10 \mathrm{~mL})$ and brine $(2 \times 10 \mathrm{~mL})$. The organic layer was dried over anhydrous sodium sulfate, filtered, and evaporated under reduced pressure to leave the crude product. The crude product was purified by reverse phase flash chromatography on $\mathrm{C} 18$, eluting with water/methanol (40/ 60) followed by evaporation of solvents to give monomers. BPA1 gives the monomer 1a, reported previously by us, ${ }^{38}$ whereas BPA2 gives a novel monomer $1 b$, obtained as a viscous liquid in $58 \%$ yield. Solubilities of $1 \mathrm{a}$ and $1 \mathrm{~b}$ are given in Table S1.

1b. ${ }^{1} \mathrm{H}$ NMR $\left(400 \mathrm{MHz}, \mathrm{CDCl}_{3}, \delta\right): 1.27\left(\mathrm{~m},{ }^{3} J_{\mathrm{HH}}=6.7\right.$ $\left.\mathrm{Hz}, 24 \mathrm{H}, \mathrm{CH}_{3}-\mathrm{CH}_{2}-\mathrm{O}\right), 1.53\left(\mathrm{~m}, 4 \mathrm{H}, \mathrm{O}-\mathrm{CH}_{2}-\mathrm{CH}_{2}-\mathrm{CH}_{2}-\right.$ $\mathrm{CH}_{2}-\mathrm{O}$ ), 1.71 (quint, ${ }^{3} \mathrm{~J}_{\mathrm{HH}}=6 \mathrm{~Hz}, 4 \mathrm{H}, \mathrm{N}-\mathrm{CH}_{2}-\mathrm{CH}_{2}-$ $\left.\mathrm{CH}_{2}-\mathrm{O}\right), 1.87\left(\mathrm{~s}, 6 \mathrm{H}, \mathrm{CH}_{3}-\mathrm{C}=\mathrm{CH}_{2}\right), 3.09\left(\mathrm{tt},{ }^{3} J_{\mathrm{HH}}=4 \mathrm{~Hz}\right.$, $\left.J_{\mathrm{HP}}=22 \mathrm{~Hz}, 2 \mathrm{H}, \mathrm{CH}-\mathrm{P}=\mathrm{O}\right), 3.33\left(\mathrm{~m}, 12 \mathrm{H}, \mathrm{CH}_{2}-\mathrm{N}, \mathrm{CH}_{2}-\right.$ O), $3.42\left(\mathrm{q},{ }^{3} J_{\mathrm{HH}}=5.3 \mathrm{~Hz}, 4 \mathrm{H}, \mathrm{CH}_{2}-\mathrm{NH}\right), 3.68\left(\mathrm{td},{ }^{3} J_{\mathrm{HH}}\right.$ $\left.=5.3 \mathrm{~Hz}, J_{\mathrm{HP}}=14 \mathrm{~Hz}, 4 \mathrm{H}, \mathrm{CH}_{2}-\mathrm{CH}-(\mathrm{P}=\mathrm{O})_{2}\right), 4.07(\mathrm{~m}$, $\left.16 \mathrm{H}, \mathrm{CH}_{2}-\mathrm{O}-\mathrm{P}=\mathrm{O}\right), 4.13\left(\mathrm{~m}, 4 \mathrm{H}, \mathrm{CH}_{2}-\mathrm{O}-\mathrm{C}=\mathrm{O}\right), 5.49$ (s, $\left.2 \mathrm{H}, \mathrm{CH}_{2}=\mathrm{C}\right), 6.06\left(\mathrm{~s}, 2 \mathrm{H}, \mathrm{CH}_{2}=\mathrm{C}\right) \mathrm{ppm}$.

${ }^{13} \mathrm{C} \mathrm{NMR}\left(100 \mathrm{MHz}, \mathrm{CDCl}_{3}, \delta\right): 16.42\left(\mathrm{CH}_{3}-\mathrm{CH}_{2}-\mathrm{O}\right)$, $18.40\left(\mathrm{CH}_{3}-\mathrm{C}=\mathrm{CH}_{2}\right), 26.32\left(\mathrm{CH}_{2}\right), 28.22\left(\mathrm{CH}_{2}-\mathrm{CH}_{2}-\mathrm{N}\right)$, 34.90, 36.18, $37.47(\mathrm{t}, \mathrm{CH}-\mathrm{P}=\mathrm{O}), 39.87\left(\mathrm{CH}_{2}-\mathrm{N}\right), 45.01$ $\left(\mathrm{CH}_{2}-\mathrm{NH}\right), 45.25\left(\mathrm{CH}_{2}-\mathrm{CH}-(\mathrm{P}=\mathrm{O})_{2}\right), 63.01,62.48$ $\left(\mathrm{CH}_{2}-\mathrm{O}-\mathrm{P}=\mathrm{O}\right), 64.14\left(\mathrm{CH}_{2}-\mathrm{O}-\mathrm{C}=\mathrm{O}\right), 67.56\left(\mathrm{CH}_{2}-\right.$ $\mathrm{O}), 70.61\left(\mathrm{CH}_{2}-\mathrm{O}\right), 125.69\left(\mathrm{CH}_{2}=\mathrm{C}\right), 136.14\left(\mathrm{CH}_{2}=\mathrm{C}\right)$, $158.13(\mathrm{~N}-\mathrm{C}=\mathrm{O}), 167.32(\mathrm{O}-\mathrm{C}=\mathrm{O}) \mathrm{ppm}$.

FT-IR (ATR): $3361(\mathrm{~N}-\mathrm{H}), 2982,2918(\mathrm{C}-\mathrm{H}), 1716$, $1636(\mathrm{C}=\mathrm{O}, \mathrm{C}=\mathrm{C}), 1537(\mathrm{~N}-\mathrm{H}), 1247(\mathrm{P}=\mathrm{O}), 1019,957$ (P-O-Et) $\mathrm{cm}^{-1}$.

General Procedure for the Synthesis of Acid Monomers $\mathbf{2 a}$ and $\mathbf{2 b}$. TMSBr $(3.6 \mathrm{mmol})$ was added dropwise to a solution of monomer $1 \mathrm{a}$ or $1 \mathrm{~b}(0.6 \mathrm{mmol})$ in dry DCM $(1.2 \mathrm{~mL})$ in an ice bath under nitrogen. The mixture was stirred for $5 \mathrm{~h}$ at $30{ }^{\circ} \mathrm{C}$. The solvent and unreacted TMSBr were removed under reduced pressure. The residue was stirred with methanol $(1.2 \mathrm{~mL})$ for $15 \mathrm{~min}$. The solution was concentrated under reduced pressure to give pure products. 1a gives monomer $2 \mathrm{a}$, reported previously by $\mathrm{us}^{38}$ and $1 \mathrm{~b}$ gives novel monomer $2 \mathrm{~b}$, obtained as a yellow waxy solid in $75 \%$ yield. Solubilities of $2 \mathrm{a}$ and $2 \mathrm{~b}$ together with $1 \mathrm{a}$ and $1 \mathrm{~b}$ are given in Table $\mathrm{S} 1$.

2b. ${ }^{1} \mathrm{H}$ NMR (400 MHz, MeOD, $\delta$ ): $1.32\left(\mathrm{t},{ }^{3} J_{\mathrm{HH}}=8 \mathrm{~Hz}\right.$, $\left.2 \mathrm{H}, \mathrm{CH}_{3}-\mathrm{CH}_{2}-\mathrm{O}\right), 1.65\left(\mathrm{~m}, 4 \mathrm{H}, \mathrm{O}-\mathrm{CH}_{2}-\mathrm{CH}_{2}-\mathrm{CH}_{2}-\right.$ $\left.\mathrm{CH}_{2}-\mathrm{O}\right), 1.83\left(\mathrm{q},{ }^{3} \mathrm{~J}_{\mathrm{HH}}=5.3 \mathrm{~Hz}, 4 \mathrm{H}, \mathrm{N}-\mathrm{CH}_{2}-\mathrm{CH}_{2}-\mathrm{CH}_{2}-\right.$ $\mathrm{O}), 1.93\left(\mathrm{~s}, 6 \mathrm{H}, \mathrm{CH}_{3}-\mathrm{C}=\mathrm{CH}_{2}\right), 2.77(\mathrm{~m}, 2 \mathrm{H}, \mathrm{CH}-\mathrm{P}=\mathrm{O})$, $3.42\left(\mathrm{~m}, 4 \mathrm{H}, \mathrm{N}-\mathrm{CH}_{2}-\mathrm{CH}_{2}-\mathrm{O}\right), 3.47\left(\mathrm{~m}, 12 \mathrm{H}, \mathrm{CH}_{2}-\mathrm{NH}\right.$, $\left.\mathrm{CH}_{2}-\mathrm{O}\right), 3.87\left(\mathrm{td},{ }^{3} J_{\mathrm{HH}}=4 \mathrm{~Hz}, J_{\mathrm{HP}}=12 \mathrm{~Hz}, 4 \mathrm{H}, \mathrm{CH}_{2}-\mathrm{CH}-\right.$ $\left.(\mathrm{P}=\mathrm{O})_{2}\right), 4.22\left(\mathrm{t},{ }^{3} \mathrm{~J}_{\mathrm{HH}}=6,4 \mathrm{H}, \mathrm{CH}_{2}-\mathrm{O}-\mathrm{C}=\mathrm{O}\right), 5.63(\mathrm{~s}$, $2 \mathrm{H}, \mathrm{CH}_{2}=\mathrm{C}$ ), $6.13\left(\mathrm{~s}, 2 \mathrm{H}, \mathrm{CH}_{2}=\mathrm{C}\right) \mathrm{ppm}$.

${ }^{13} \mathrm{C}$ NMR (100 MHz, MeOD, $\delta$ ): $16.95\left(\mathrm{CH}_{3}-\mathrm{C}=\mathrm{CH}_{2}\right)$, $25.98\left(\mathrm{CH}_{2}\right), 27.01\left(\mathrm{CH}_{2}-\mathrm{CH}_{2}-\mathrm{N}\right), 37.16(\mathrm{CH}-\mathrm{P}=\mathrm{O})$, $39.35\left(\mathrm{CH}_{2}-\mathrm{N}\right), 39.42\left(\mathrm{CH}_{2}-\mathrm{NH}\right), 44.12\left(\mathrm{CH}_{2}-\mathrm{CH}-(\mathrm{P}=\right.$ $\left.\mathrm{O})_{2}\right), 63.15\left(\mathrm{CH}_{2}-\mathrm{O}-\mathrm{C}=\mathrm{O}\right), 67.10 \quad\left(\mathrm{CH}_{2}-\mathrm{O}\right), \quad 70.24$ $\left(\mathrm{CH}_{2}-\mathrm{O}\right), 125.01\left(\mathrm{CH}_{2}=\mathrm{C}\right), 136.03\left(\mathrm{CH}_{2}=\mathrm{C}\right), 159.41$ $(\mathrm{N}-\mathrm{C}=\mathrm{O}), 167.19(\mathrm{O}-\mathrm{C}=\mathrm{O}) \mathrm{ppm}$.
FTIR (ATR): $3301(\mathrm{O}-\mathrm{H}), 2942,2862(\mathrm{C}-\mathrm{H}), 1712$, $1699(\mathrm{C}=\mathrm{O}), 1632(\mathrm{C}=\mathrm{C}), 1557(\mathrm{~N}-\mathrm{H}), 1159(\mathrm{P}=\mathrm{O})$, 996, $912(\mathrm{P}-\mathrm{O}) \mathrm{cm}^{-1}$.

Synthesis of Hydrogels. Bisphosphonic acid-functionalized monomer ( $2 \mathrm{a}$ or $2 \mathrm{~b}$ ) and HEMA were dissolved in water at various concentrations to form precursor solutions of hydrogels (Table 1). Irgacure 2959 (2 wt \% of total monomer weight) was added as a photoinitiator and the mixtures were polymerized by exposure to UV light $(365 \mathrm{~nm})$ for $30 \mathrm{~min}$ in vials (for mineralization studies) and syringes (for swelling and mechanical measurements). For the gel fraction measurements, cylindrical gel specimens of about $9 \mathrm{~mm}$ in diameter and $6 \mathrm{~mm}$ in length were weighed $\left(W_{1}\right)$ and immersed in ethanol for $24 \mathrm{~h}$ and then in water for $12 \mathrm{~h}$ to remove unreacted monomers. The swollen samples were lyophilized and weighed again to obtain $W_{2}$. The gel fraction $W_{\mathrm{g}}$ that is the fraction of waterinsoluble polymer was calculated as

$$
W_{\mathrm{g}}=\frac{W_{2}}{W_{1}\left(\frac{C_{0}}{100}\right)} \times 100
$$

where $C_{0}$ is the initial monomer concentration (in wt \%).

Swelling Studies. Swelling studies were performed by immersing dry hydrogel samples into water and $1 \mathrm{M} \mathrm{CaCl}_{2}$ solutions at $37^{\circ} \mathrm{C}$. The gels were removed from the swelling medium after $12 \mathrm{~h}$, blotted on filter paper, and weighed. The SP was calculated using the following equation ${ }^{48}$

$$
\mathrm{SP}=\frac{W_{\mathrm{s}}-W_{\mathrm{d}}}{W_{\mathrm{d}}} \times 100
$$

where $W_{\mathrm{s}}$ and $W_{\mathrm{d}}$ refer to the weight of swollen and dry gel samples, respectively. The average data obtained from triplicate measurements were reported.

Mineralization of Hydrogels. SBF was prepared as described by Kokubo and Takadama. ${ }^{49}$ Buffer solution (2 L, $\mathrm{pH}=7.4)$ containing $142 \mathrm{mM} \mathrm{Na}^{+}, 5 \mathrm{mM} \mathrm{K}^{+}, 1.5 \mathrm{mM} \mathrm{Mg}^{2+}$, $2.5 \mathrm{mM} \mathrm{Ca}^{2+}, 147.8 \mathrm{mM} \mathrm{Cl}^{-}, 4.2 \mathrm{mM} \mathrm{HCO}_{3}{ }^{-}, 1 \mathrm{mM} \mathrm{HPO}_{4}{ }^{2-}$, and $0.5 \mathrm{mM} \mathrm{SO}_{4}{ }^{2-}$ was prepared in ultrapure water. This solution was then filter sterilized (Millipore, sterivex filter unit, $0.22 \mu \mathrm{m})$ and stored at $+4{ }^{\circ} \mathrm{C}$. Hydrogel samples were soaked in SBF solution or ultrapure water (control) and incubated at $37{ }^{\circ} \mathrm{C}$ with gentle shaking (50 rpm) for 2 and 4 weeks, respectively, during which buffer/water was replaced with fresh one every day. The hydrogel samples were then taken out of the solution, rinsed with ultrapure water twice, and then freezedried to constant weight.

Characterization of Mineralized Hydrogels. The morphology of the hydrogels was analyzed via SEM (Zeiss Ultra Plus, Bruker). The freeze-dried samples were coated with a thin layer of carbon, and $10 \mathrm{kV}$ acceleration voltage was used for imaging. An EDX detector (Bruker XFlash $5010123 \mathrm{eV}$ ) was used for elemental analysis of mineral grown on hydrogels. The chemical compositions were analyzed by powder XRD (D2 PHASER, Bruker, MA) measurements.

Determination of $\mathrm{Ca}^{2+}$ Content. The $\mathrm{Ca}^{2+}$ content was measured by the procedure described in the literature. ${ }^{49}$ Mineralized hydrogel samples were first lyophilized and then homogenized in $0.5 \mathrm{~mL}$ of $0.5 \mathrm{~N} \mathrm{HCl}$. The solution was shaken at $175 \mathrm{rpm}$ for $24 \mathrm{~h}$, and mechanical force was applied. To achieve complete dissolution of the hydrogels, the shaking was repeated overnight. The $\mathrm{Ca}^{2+}$ concentration in the solution was measured by spectrophotometric analysis using cresolphthalein complexone and Calcium Reagent (Pointe Scientific). 
A standard curve was generated by using standard solutions in the range of $0.01-0.2 \mathrm{mg} / \mathrm{mL} \mathrm{Ca}{ }^{2+}$ and the $\mathrm{Ca}^{2+}$ content was normalized to the dry weight of the sample.

Mechanical Properties. Mechanical properties of the hydrogels in equilibrium with water or $1 \mathrm{M} \mathrm{CaCl}_{2}$ solution were determined through uniaxial compression measurements on a Zwick Roell test machine using a $500 \mathrm{~N}$ load cell in a thermostated room at $23 \pm 2{ }^{\circ} \mathrm{C}$. Before the tests, a complete contact between the gel specimen and the metal plate was provided by applying an initial compressive force of $0.01 \mathrm{~N}$. The tests were carried out at a constant cross-head speed of 1.8 $\times 10^{-2} \mathrm{~s}^{-1}$. The stress was calculated as its nominal $\sigma_{\text {nom }}$ and true values $\sigma_{\text {true }}\left(=\lambda \sigma_{\text {nom }}\right)$, which are the forces per crosssectional area of the undeformed and deformed gel samples, respectively, and $\lambda$ is the compression ratio. The strain is given by $\varepsilon$ which is the change in the specimen length with respect to its initial length, that is, $\varepsilon=1-\lambda$. The compressive strength and strain at break of the hydrogels were calculated from the maxima in $\sigma_{\text {true }}$ versus $\varepsilon$ curves as detailed before. ${ }^{50}$ Young's modulus $E$ of the hydrogels was calculated from the slope of stress-strain curves between 5 and 15\% compressions. Cyclic compression tests were conducted at a constant cross-head speed of $1.8 \times 10^{-2} \mathrm{~s}^{-1}$ to a maximum compression ratio, followed by retraction to zero force and a waiting time of $5 \mathrm{~min}$ until the next cycle.

\section{ASSOCIATED CONTENT}

\section{S Supporting Information}

The Supporting Information is available free of charge on the ACS Publications website at DOI: 10.1021/acsomega.8b01103.

Solubilities of the cross-linkers in selected solvents and Young's modulus $E$ and fracture stress $\sigma_{\mathrm{f}}$ of the hydrogels in water (circles) and in aqueous $1 \mathrm{M} \mathrm{CaCl}_{2}$ solution (triangles) plotted against the cross-linker content. Cross-linker $=2 \mathrm{a}$ (filled symbols) and $2 \mathrm{~b}$ (open symbols). Total monomer concentration $=25 \mathrm{wt}$ $\%$ (PDF)

\section{AUTHOR INFORMATION}

\section{Corresponding Author}

*E-mail: avcid@boun.edu.tr (D.A.).

\section{ORCID $\odot$}

Seda Kizilel: 0000-0001-9092-2698

Oguz Okay: 0000-0003-2717-4150

Duygu Avci: 0000-0002-9927-0291

\section{Author Contributions}

${ }^{\perp}$ M.N.G. and M.S.A. made equal contributions.

Notes

The authors declare no competing financial interest.

\section{ACKNOWLEDGMENTS}

The authors would like to acknowledge the financial support from Bogazici University Research Fund (11820). O.O. thanks the Turkish Academy of Sciences (TUBA) for the partial support.

\section{REFERENCES}

(1) Caló, E.; Khutoryanskiy, V. V. Biomedical applications of hydrogels: A review of patents and commercial products. Eur. Polym. J. 2015, 65, 252-267.
(2) Drury, J. L.; Mooney, D. J. Hydrogels for tissue engineering: Scaffold design variables and applications. Biomaterials 2003, 24, 4337-4351.

(3) Gkioni, K.; Leeuwenburgh, S. C. G.; Douglas, T. E. L.; Mikos, A. G.; Jansen, J. A. Mineralization of hydrogels for bone regeneration. Tissue Eng., Part B 2010, 16, 577-585.

(4) Sailaja, G. S.; Ramesh, P.; Vellappally, S.; Anil, S.; Varma, H. K. Biomimetic approaches with smart interfaces for bone regeneration. J. Biomed. Sci. 2016, 23, 77.

(5) Chirila, T. V.; Zainuddin. Calcification of synthetic polymers functionalized with negatively ionizable groups: A critical review. React. Funct. Polym. 2007, 67, 165-172.

(6) Slaughter, B. V.; Khurshid, S. S.; Fisher, O. Z.; Khademhosseini, A.; Peppas, N. A. Hydrogels in regenerative medicine. Adv. Mater. 2009, 21, 3307-3329.

(7) Salgado, A. J.; Coutinho, O. P.; Reis, R. L. Bone tissue engineering: State of the art and future trends. Macromol. Biosci. 2004, $4,743-765$.

(8) Kepa, K.; Coleman, R.; Grøndahl, L. In vitro mineralization of functional polymers. Biosurf. Biotribol. 2015, 1, 214-227.

(9) Zhong, C.; Chu, C. C. Biomimetic mineralization of acid polysaccharide-based hydrogels: Towards porous 3-dimensional bone-like biocomposites. J. Mater. Chem. 2012, 22, 6080-6087.

(10) Zhou, L.; Tan, G.; Tan, Y.; Wang, H.; Liao, J.; Ning, C. Biomimetic mineralization of anionic gelatin hydrogels: Effect of degree of methacrylation. RSC Adv. 2014, 4, 21997-22008.

(11) Murphy, W. L.; Mooney, D. J. Bioinspired Growth of Crystalline Carbonate Apatite on Biodegradable Polymer Substrata. J. Am. Chem. Soc. 2002, 124, 1910-1917.

(12) Farbod, K.; Nejadnik, M. R.; Jansen, J. A.; Leeuwenburgh, S. C. $\mathrm{G}$. Interactions between inorganic and organic phases in bone tissue as a source of inspiration for design of novel nanocomposites. Tissue Eng., Part B 2014, 20, 173-188.

(13) Song, J.; Saiz, E.; Bertozzi, C. R. A new approach to mineralization of biocompatible hydrogel scaffolds: An efficient process toward 3-dimensional bonelike composites. J. Am. Chem. Soc. 2003, 125, 1236-1243.

(14) Phadke, A.; Zhang, C.; Hwang, Y.; Vecchio, K.; Varghese, S. Templated mineralization of synthetic hydrogels for bone-like composite materials: Role of matrix hydrophobicity. Biomacromolecules 2010, 11, 2060-2068.

(15) Huang, J.; Liu, G.; Song, C.; Saiz, E.; Tomsia, A. P. Role of molecular chemistry of degradable pHEMA hydrogels in threedimensional biomimetic mineralization. Chem. Mater. 2012, 24, 1331-1337.

(16) Watson, B. M.; Kasper, F. K.; Mikos, A. G. Phosphoruscontaining polymers for regenerative medicine. Biomed. Mater. 2014, 9, 025014.

(17) Watson, B. M.; Kasper, F. K.; Engel, P. S.; Mikos, A. G. Synthesis and characterization of injectable, biodegradable, phosphate-containing, chemically cross-linkable, thermoresponsive macromers for bone tissue engineering. Biomacromolecules 2014, 15, 17881796.

(18) Gemeinhart, R. A.; Bare, C. M.; Haasch, R. T.; Gemeinhart, E. $\mathrm{J}$. Osteoblast-like cell attachment to and calcification of novel phosphonate-containing polymeric substrates. J. Biomed. Mater. Res., Part A 2006, 78, 433-440.

(19) Tan, J.; Gemeinhart, R. A.; Ma, M.; Saltzman, W. M. Improved cell adhesion and proliferation on synthetic phosphonic acidcontaining hydrogels. Biomaterials 2005, 26, 3663-3671.

(20) Nuttelman, C. R.; Benoit, D. S. W.; Tripodi, M. C.; Anseth, K. $S$. The effect of ethylene glycol methacrylate phosphate in PEG hydrogels on mineralization and viability of encapsulated hMSCs. Biomaterials 2006, 27, 1377-1386.

(21) Bingol, H. B.; Altin, A.; Bal, T.; Agopcan-Cinar, S.; Kizilel, S.; Avci, D. Synthesis and evaluation of new phosphonic acid-functionalized acrylamides with potential biomedical applications. J. Polym. Sci., Part A: Polym. Chem. 2015, 53, 2755-2767. 
(22) Stancu, I. C.; Filmon, R.; Cincu, C.; Marculescu, B.; Zaharia, C.; Tourmen, Y.; Baslé, M. F.; Chappard, D. Synthesis of methacryloyloxyethyl phosphate copolymers and in vitro calcification capacity. Biomaterials 2004, 25, 205-213.

(23) Li, Q.; Wang, J.; Shahani, S.; Sun, D. D. N.; Sharma, B.; Elisseeff, J. H.; Leong, K. W. Biodegradable and photocrosslinkable polyphosphoester hydrogel. Biomaterials 2006, 27, 1027-1034.

(24) Wang, D.-A.; Williams, C. G.; Yang, F.; Cher, N.; Lee, H.; Elisseeff, J. H. Bioresponsive phosphoester hydrogels for bone tissue engineering. Tissue Eng. 2005, 11, 201-213.

(25) Yin, Y. J.; Luo, X. Y.; Cui, J. F.; Wang, C. Y.; Guo, X. M.; Yao, K. D. A Study on Biomineralization Behavior ofN-Methylene Phosphochitosan Scaffolds. Macromol. Biosci. 2004, 4, 971-977.

(26) Kim, S. Y.; Lee, S. C. Thermo-responsive injectable hydrogel system based on poly( $\mathrm{N}$-isopropylacrylamide-co-vinylphosphonic acid). I. Biomineralization and protein delivery. J. Appl. Polym. Sci. 2009, 113, 3460-3469.

(27) Wang, D.; Williams, C. G.; Li, Q.; Sharma, B.; Elisseeff, J. H. Synthesis and characterization of a novel degradable phosphatecontaining hydrogel. Biomaterials 2003, 24, 3969-3980.

(28) Russell, R. G. G. Bisphosphonates: Mode of action and pharmacology. Pediatrics 2007, 119, S150-S162.

(29) Boivin, G.; Meunier, P. J. Effects of bisphosphonates on matrix mineralization. J. Musculoskeletal Neuronal Interact. 2002, 2, 538-543.

(30) Cattalini, J. P.; Boccaccini, A. R.; Lucangioli, S.; Mouriño, V. Bisphosphonate-based strategies for bone tissue engineering and orthopedic implants. Tissue Eng., Part B 2012, 18, 323-340.

(31) Yang, X.; Akhtar, S.; Rubino, S.; Leifer, K.; Hilborn, J.; Ossipov, D. Direct "Click" Synthesis of Hybrid Bisphosphonate-Hyaluronic Acid Hydrogel in Aqueous Solution for Biomineralization. Chem. Mater. 2012, 24, 1690-1697.

(32) Kootala, S.; Zhang, Y.; Ghalib, S.; Tolmachev, V.; Hilborn, J.; Ossipov, D. A. Control of growth factor binding and release in bisphosphonate functionalized hydrogels guides rapid differentiation of precursor cells in vitro. Biomater. Sci. 2016, 4, 250-254.

(33) Hulsart-Billström, G.; Yuen, P. K.; Marsell, R.; Hilborn, J.; Larsson, S.; Ossipov, D. Bisphosphonate-linked hyaluronic acid hydrogel sequesters and enzymatically releases active bone morphogenetic protein-2 for induction of osteogenic differentiation. Biomacromolecules 2013, 14, 3055-3063.

(34) Yi, Z.; Zhang, Y.; Kootala, S.; Hilborn, J.; Ossipov, D. A. Hydrogel patterning by diffusion through the matrix and subsequent light-triggered chemical immobilization. ACS Appl. Mater. Interfaces 2015, 7, 1194-1206.

(35) Nejadnik, M. R.; Yang, X.; Bongio, M.; Alghamdi, H. S.; van den Beucken, J. J. J. P.; Huysmans, M. C.; Jansen, J. A.; Hilborn, J.; Ossipov, D.; Leeuwenburgh, S. C. G. Self-healing hybrid nanocomposites consisting of bisphosphonated hyaluronan and calcium phosphate nanoparticles. Biomaterials 2014, 35, 6918-6929.

(36) Diba, M.; An, J.; Schmidt, S.; Hembury, M.; Ossipov, D.; Boccaccini, A. R.; Leeuwenburgh, S. C. G. Exploiting BisphosphonateBioactive-Glass Interactions for the Development of Self-Healing and Bioactive Composite Hydrogels. Macromol. Rapid Commun. 2016, 37, 1952-1959.

(37) Diba, M.; Camargo, W. A.; Brindisi, M.; Farbod, K.; Klymov, A.; Schmidt, S.; Harrington, M. J.; Draghi, L.; Boccaccini, A. R.; Jansen, J. A.; van den Beucken, J. J. J. P.; Leeuwenburgh, S. C. G. Composite colloidal gels made of bisphosphonate-functionalized gelatin and bioactive glass particles for regeneration of osteoporotic bone defects. Adv. Funct. Mater. 2017, 27, 1703438.

(38) Guven, M. N.; Akyol, E.; Duman, F. D.; Acar, H. Y.; Karahan, O.; Avci, D. Urea dimethacrylates functionalized with bisphosphonate/bisphosphonic acid for improved dental materials. J. Polym. Sci., Part A: Polym. Chem. 2017, 55, 3195-3204.

(39) Guven, M. N.; Altuncu, M. S.; Duman, F. D.; Eren, T. N.; Acar, H. Y.; Avci, D. Bisphosphonate-functionalized poly ( $\beta$-amino ester $)$ network polymers. J. Biomed. Mater. Res., Part A 2017, 105, 14121421.
(40) Feitosa, V. P.; Ogliari, F. A.; Van Meerbeek, B.; Watson, T. F.; Yoshihara, K.; Ogliari, A. O.; Sinhoreti, M. A.; Correr, A. B.; Cama, G.; Sauro, S. Can the hydrophilicity of functional monomers affect chemical interaction? J. Dent. Res. 2014, 93, 201-206.

(41) Mayer, I.; Schlam, R.; Featherstone, J. D. B. Magnesiumcontaining carbonate apatites. J. Inorg. Biochem. 1997, 66, 1-6.

(42) Suzuki, S.; Whittaker, M. R.; Grøndahl, L.; Monteiro, M. J.; Wentrup-Byrne, E. Synthesis of soluble phosphate polymers by RAFT and their in vitro mineralization. Biomacromolecules 2006, 7, 31783187.

(43) Hamade, E.; Azzar, G.; Radisson, J.; Buchet, R.; Roux, B. Chick embryo anchored alkaline phosphatase and mineralization process in vitro. Influence of $\mathrm{Ca} 2+$ and nature of substrates. Eur. J. Biochem. 2003, 270, 2082-2090.

(44) Narasaraju, T. S. B.; Phebe, D. E. Some physico-chemical aspects of hydroxylapatite. J. Mater. Sci. 1996, 31, 1-21.

(45) Webber, R. E.; Creton, C.; Brown, H. R.; Gong, J. P. Large strain hysteresis and mullins effect of tough double-network hydrogels. Macromolecules 2007, 40, 2919-2927.

(46) Tuncaboylu, D. C.; Sahin, M.; Argun, A.; Oppermann, W.; Okay, O. Dynamics and large strain behavior of self-healing hydrogels with and without surfactants. Macromolecules 2012, 45, 1991-2000.

(47) Degenhardt, C. R.; Burdsall, D. C. Synthesis of ethenylidenebis(phosphonic acid) and its tetraalkyl esters. J. Org. Chem. 1986, 51, 3488-3490.

(48) Beria, L.; Gevrek, T. N.; Erdog, A.; Sanyal, R.; Pasini, D.; Sanyal, A. 'Clickable' hydrogels for all: facile fabrication and functionalization. Biomater. Sci. 2014, 2, 67-75.

(49) Kokubo, T.; Takadama, H. How useful is SBF in predicting in vivo bone bioactivity? Biomaterials 2006, 27, 2907-2915.

(50) Argun, A.; Can, V.; Altun, U.; Okay, O. Nonionic Double and Triple Network Hydrogels of High Mechanical Strength. Macromolecules 2014, 47, 6430-6440. 